\title{
PI3K/Akt signaling pathway-induced heme oxygenase-1 upregulation mediates the adaptive cytoprotection of hydrogen peroxide preconditioning against oxidative injury in PC12 cells
}

\author{
LIQIU MO ${ }^{1,2}$, CHUNTAO YANG ${ }^{4}$, MOFA GU ${ }^{5}$, DONGDAN ZHENG ${ }^{3}$, LIN LIN $^{2}$, \\ XIUYU WANG ${ }^{1}$, AIPING LAN ${ }^{1}$, FEN HU ${ }^{1}$ and JIANQIANG FENG ${ }^{1}$ \\ ${ }^{1}$ Department of Physiology, Zhongshan School of Medicine; Departments of ${ }^{2}$ Anesthesiology and ${ }^{3}$ Cardiology, \\ Huangpu Division of The First Affiliated Hospital, Sun Yat-sen University; ${ }^{4}$ Department of Physiology, \\ Guangzhou Medical University; ${ }^{5}$ Department of Radiology, Sun Yat-sen University \\ Cancer Center, Sun Yat-sen University, Guangzhou, P.R. China
}

Received February 8, 2012; Accepted April 2, 2012

DOI: $10.3892 /$ ijmm.2012.1002

\begin{abstract}
Both the phosphatidylinositol 3-kinase (PI3K)/Akt pathway and heme oxygenase-1 (HO-1) create a survival signal against oxidative stress-induced injuries. Although we have demonstrated that hydrogen peroxide $\left(\mathrm{H}_{2} \mathrm{O}_{2}\right)$ preconditioning confers adaptive cytoprotection against oxidative stressinduced injury in PC12 cells, it remains unknown whether these defense systems are involved in the protective effect of $\mathrm{H}_{2} \mathrm{O}_{2}$ preconditioning. In the current study, $\mathrm{PC} 12$ cells were preconditioned with $100 \mu \mathrm{M} \mathrm{H}_{2} \mathrm{O}_{2}$ for $90 \mathrm{~min}$, followed by $24 \mathrm{~h}$ recovery and subsequent exposure to $300 \mu \mathrm{M} \mathrm{H}_{2} \mathrm{O}_{2}$ for further $12 \mathrm{~h}$. The findings showed that preconditioning with $100 \mu \mathrm{M}$ $\mathrm{H}_{2} \mathrm{O}_{2}$ upregulated HO-1 expression. Zinc protoporphyrin IX (ZnPP), a selective inhibitor of HO-1, at a concentration of $15 \mu \mathrm{M}$, significantly attenuated $\mathrm{H}_{2} \mathrm{O}_{2}$ preconditioning-elicited cytotoxicity, apoptosis, oxidative stress and mitochondrial membrane potential $(\Delta \Psi \mathrm{m})$ loss in PC12 cells. In addition, $\mathrm{H}_{2} \mathrm{O}_{2}$ preconditioning enhanced phosphorylation of Akt. Treatment with $25 \mu \mathrm{M}$ LY294002, a selective inhibitor of PI3K, for 20 min before $\mathrm{H}_{2} \mathrm{O}_{2}$ preconditioning blocked not only $\mathrm{H}_{2} \mathrm{O}_{2}$ preconditioning-induced $\mathrm{HO}-1$ induction, but also the protective effect of $\mathrm{H}_{2} \mathrm{O}_{2}$ preconditioning against cytotoxicity. The present study provides novel evidence for the effect of preconditioning with $\mathrm{H}_{2} \mathrm{O}_{2}$ on the induction of $\mathrm{HO}-1$, which contributes to the adaptive cytoprotection of $\mathrm{H}_{2} \mathrm{O}_{2}$ preconditioning against oxidative stress-induced cellular injury via a $\mathrm{PI} 3 \mathrm{~K} / \mathrm{Akt}$-dependent mechanism in PC12 cells.
\end{abstract}

Correspondence to: Professor Jianqiang Feng, Department of Physiology, Zhongshan School of Medicine, Sun Yat-sen University, Guangzhou 510080, P.R. China

E-mail: fengjq-sums@163.com

Key words: phosphatidylinostol 3-kinase, heme oxygenase-1, hydrogen peroxide preconditioning, cytoprotection, oxidative stress

\section{Introduction}

It is well known that ischemic preconditioning (IPC) has adaptive cardioprotective effect (1). To date, this concept has been extended to preconditioning induced by non-ischemic stress, such as temperature $(2)$, hypoxia $(3,4)$, anesthetic $(5,6)$ and reactive oxygen species (ROS) (7-9).

Recently, we have demonstrated that hydrogen peroxide $\left(\mathrm{H}_{2} \mathrm{O}_{2}\right)$ preconditioning protects $\mathrm{PC} 12$ cells against apoptosis induced by oxidative stress (10-13). This cytoprotection by $\mathrm{H}_{2} \mathrm{O}_{2}$ preconditioning is associated with blockade of the decrease in the expression of Bcl-2 and generation of ROS (10), as well as overexpression of inducible nitric oxide synhase (iNOS) and cycloxygenase-2 (COX-2) (11), activation of the Janus tyrosine kinases (JAK)-signal transducer activator of transcription (STAT) pathway (12) and the transcription factor, nuclear factor- $\mathrm{\kappa B}(\mathrm{NF}-\kappa \mathrm{B})(13)$. These findings suggest that the molecular mechanisms responsible for $\mathrm{H}_{2} \mathrm{O}_{2}$ preconditioningelicited adaptive cytoprotection may be complex and related to multiple genes and signaling pathways.

Inducible heme oxygenase-1 (HO-1), also known as HSP32 (heat shock protein of $32 \mathrm{kDa}$ ), is a stress response protein, which is response to multiple oxidative insults, such as heme, UV light, heavy metal, glutathione depletion and $\mathrm{H}_{2} \mathrm{O}_{2}$. This enzyme catalyzes the stepwise degradation of heme to release free iron and equimolar concentrations of carbon monoxide (CO) and the linear tetrapyrrol biliverdin, which is converted to bilirubin by the enzyme biliverdin reductase (14). Increasing evidence has demonstrated the potent antioxidant activity of the heme-derived metabolites produced by $\mathrm{HO}-1$ catalysis (biliverdin and bilirubin) and the cytoprotective effects of $\mathrm{CO}$ on vascular endothelium and neuronal cells (14-17). In addition, the HO-1-deficient mice exhibit a serious damage of iron metabolism, resulting in liver and kidney oxidative insult and inflammation (18). Cells from mice with a target deletion of HO-1 are much more sensitive to apoptosis induced by serum deprivation, an effect that is significantly attenuated by overexpression of HO-1 (19). HO-1 induction in the brain also reduces stroke-related ischemic injury and might 
contribute to the main neuroprotective effect of statins (20). A recent study has demonstrated that induction of HO-1 is involved in the neuroprotection of chondroitin sulfate against oxidative stress (21). Therefore, it is now widely accepted that induction of HO-1 expression represents an adaptive response that enhances cell resistance to noxious stimuli, including oxidative stress. Interestingly, the previous studies have shown that hyperbaric oxygen (HBO; i.e. exposure to pure oxygen under high ambient pressure) pretreatment confers an adaptive protection against $\mathrm{H}_{2} \mathrm{O}_{2}$-induced DNA damage in blood cells (22). This protection is associated with HO-1 induction (23). However, whether HO-1 is implicated in the adaptive cytoprotective effect of $\mathrm{H}_{2} \mathrm{O}_{2}$ preconditioning in neuronal cells is unclear.

Recently, the role of phosphatidylinositol 3-kinase/ Akt (PI3K/Akt) pathway in transcriptional regulation has gained attention. PI3Ks and their downstream target Akt (also known as protein kinase B) are a conserved family of signal transduction enzymes which play important roles in suppressing apoptosis and in promoting cell growth and proliferation (21,24-26). Salinas et al (27) reported that the PI3K/Akt pathway participates in nerve growth factor (NGF)elicited attenuation of the intracellular ROS by regulating the expression of HO-1. In addition, in human neuroblastoma SH-SY5Y cells subjected to oxidative stress, such as $\mathrm{H}_{2} \mathrm{O}_{2}$, $\mathrm{PI} 3 \mathrm{~K} / \mathrm{Akt}$-mediated induction of HO-1 contributes to the neuroprotective effect of chondroitin sulfate, an endogenous perineuronal net glycosaminoglycan (21). The participation of the survival pathway PI3K/Akt in the regulation of HO-1 has also described in other cellular context, including the response to endotoxin (28), arsenite (29) and carnosol (30).

In the present study, we analyzed the following questions: i) effects of $\mathrm{H}_{2} \mathrm{O}_{2}$ preconditioning on the expression of $\mathrm{HO}-1$ and $\mathrm{Akt}$; ii) roles of $\mathrm{HO}-1$ and $\mathrm{PI} 3 \mathrm{~K} / \mathrm{Akt}$ pathway in the protective effects of $\mathrm{H}_{2} \mathrm{O}_{2}$ preconditioning against oxidative stress injury; iii) regulatory effect of $\mathrm{PI} 3 \mathrm{k} / \mathrm{Akt}$ on the induction of $\mathrm{HO}-1$ by $\mathrm{H}_{2} \mathrm{O}_{2}$ preconditioning. The findings of this study provide new evidence that $\mathrm{H}_{2} \mathrm{O}_{2}$ preconditioning protects $\mathrm{PC} 12$ cells against oxidative stress injury by inducing $\mathrm{HO}-1$ via the $\mathrm{PI} 3 \mathrm{~K} /$ Akt signaling pathway.

\section{Materials and methods}

Materials. 3-(4,5-dimethyl-thiazol-2-yl)-2,5-diphenyltetrazolium bromide (MTT), propidium iodide (PI), RNase, 2',7'-dichlorodihydrofluorescein diacetate (DCFH-DA), rhodamine 123 (Rh123) and zinc protoporphyrin IX (ZnPP) were purchased from Sigma-Aldrich (St. Louis, MO, USA). RPMI1640 medium, horse serum and fetal bovine serum (FBS) were supplied by Gibco-BRL (Calsbad, CA, USA). HO-1 antibody was purchased from StressGen Biotech (Victoria, BC, Canada). Total (t)-Akt and phosphorylated (p)-Akt antibodies were from Cell Signaling Technology (Danvers, MA, USA). Ly294002 was supplied by Calbiochem (Schwalbach, Germany). Caspase-Glo 3/7 kit was purchased from Promega (Madison, WI, USA).

Cell culture and preconditioning protocols. The rat pheochromocytoma cell line, PC12 cell, was obtained from the Sun Yat-sen University Experimental Animal Center (Guangzhou,
China). PC12 cells were grown in RPMI-1640 medium supplemented with 5\% heat-inactivated horse serum and 10\% FBS at $37^{\circ} \mathrm{C}$ under an atmosphere of $5 \% \mathrm{CO}_{2}$ and $95 \%$ air.

PC12 cells were preconditioned with $100 \mu \mathrm{M} \mathrm{H}_{2} \mathrm{O}_{2}$ for $90 \mathrm{~min}$, followed by $24 \mathrm{~h}$ recovery and subsequent exposure to $300 \mu \mathrm{M} \mathrm{H}_{2} \mathrm{O}_{2}$ for $12 \mathrm{~h}$. $\mathrm{HO}-1$ inhibitor (ZnPP) at $15 \mu \mathrm{M}$ or PI3K inhibitor (Ly294002) at $25 \mu \mathrm{M}$ was administered $20 \mathrm{~min}$ before preconditioning with $100 \mu \mathrm{M} \mathrm{H}_{2} \mathrm{O}_{2}$.

Determination of cell viability. Cell viability was determined by the conventional MTT reduction assay. The PC12 cells were plated at a density of $5 \times 10^{4}$ cells/well in 96 -well plates. After the indicated treatments, cells were co-incubated with MTT solution (a final concentration of $0.5 \mathrm{mg} / \mathrm{ml}$ ) for $4 \mathrm{~h}$. The medium was removed and $150 \mu \mathrm{l}$ dimethyl sulphoxide (DMSO) was added to each well. The formazan dye crystal was solubilized for $15 \mathrm{~min}$ and absorbance was measured at $570 \mathrm{~nm}$ with a microplate reader (Molecular Devices, Sunnyvale, CA, USA). The mean optical density (OD) in the indicated groups was used to calculate percentage of cell viability according to the formula below: percentage of cell viability = OD treatment group/OD control group x $100 \%$. Experiments were preformed in triplicate.

Flow cytometry analysis of apoptosis. After different treatments, PC12 cells were harvested and washed twice with phosphate buffer solution (PBS) and fixed with $70 \%$ ice-cold ethanol. After centrifugation, PC12 cells were adjusted to a concentration of $1 \times 10^{6}$ cells $/ \mathrm{ml}$ and then $0.5 \mathrm{ml}$ RNase $(1 \mathrm{mg} / \mathrm{ml}$ in PBS) was added to a $0.5 \mathrm{ml}$ cell sample. After gentle mixing with $50 \mathrm{mg} / 1 \mathrm{PI}$, mixed cells were filtered and incubated in the dark at $4^{\circ} \mathrm{C}$ for 30 min before flow cytometric analysis. The PI fluorescence of individual nuclei was measured by a flow cytometer (Beckman-Coulter, Los Angeles, CA, USA). In the DNA histogram, the amplitude of the sub-G1 DNA peak, which is lower than the G1 DNA peak, represents the number of apoptotic cells.

Assay for caspase-3/-7 activity. PC12 cells were plated in 96-well plates at a density of $1 \times 10^{4}$ cells/well. After the indicated treatments, caspases- 3 and -7 activation were measured by caspase-Glo 3/7 assay (Promega) according to the manufacture's instructions. The assay provides a proluminescent caspase-3/-7 substrate which can be cleaved to aminoluciferin. The released aminoluciferin is a substrate which is consumed by luciferase, generating a luminescent signal. The signal is proportional to caspase-3/-7 activity. The experiment was performed at least three times with similar outcomes.

Measurement of intracellular ROS generation. Intracellular ROS levels were determined by fluorescent DCF derived from cell-permeable DCFH-DA. After treatment with indicated conditioned mediums, $\mathrm{PC} 12$ cells were incubated with $10 \mu \mathrm{M}$ DCFH-DA solution at $37^{\circ} \mathrm{C}$ for $30 \mathrm{~min}$ in the dark. DCF fluorescence was measured over the entire field of vision with a fluorescent microscope connected to an imaging system (BX50-FLA; Olympus, Tokyo, Japan). Mean fluorescence intensity (MFI) of DCF from 3 random fields was analyzed with ImageJ 1.410 software (National Institutes of Health (NIH), Bethesda, MD, USA). 
Measurement of mitochondrial membrane potential ( $\Delta \Psi m)$. $\Delta \Psi \mathrm{m}$ was monitored by a fluorescent dye Rh123, a cell-permeable cationic dye that preferentially enters into mitochondria based on the highly negative $\Delta \Psi \mathrm{m}$. Depolarization of $\Delta \Psi \mathrm{m}$ results in the loss of Rh123 from the mitochondria and a decrease in intracellular fluorescence. In the present study, $\mathrm{Rh} 123(100 \mathrm{mg} / \mathrm{l})$ was added to cell cultures for $45 \mathrm{~min}$ at $37^{\circ} \mathrm{C}$ and fluorescence was measured over the entire field of vision by using a fluorescence microscope connected to an imaging system (BX50-FLA; Olympus). MFI of Rh123 from 3 random fields was analyzed with ImageJ 1.41 o software and the MFI was taken as an index of the level of $\Delta \Psi \mathrm{m}$.

Western blotting assay. At the end of the treatments, PC12 cells were harvested and re-suspended in ice-cold cell lysis solution and the homogenate was centrifuged at $10,000 \mathrm{xg}$ for $15 \mathrm{~min}$ at $4^{\circ} \mathrm{C}$. After quantitated with the BCA protein assay kit (Kangchen Biotech, Shanghai, China), proteins were separated by $12 \%$ SDS-PAGE. The proteins in the gel were transferred into polyvinylidene difluoride (PVDF) membrane. After blocking with 5\% fat-free dry milk in TBS-T for $1 \mathrm{~h}$ at room temperature, the membrane was incubated with the primary antibodies specific to HO-1 (1:1,000 dilution), t-Akt (1:1,000 dilution), p-Akt (1:1,000 dilution), or horseradish peroxidase (HRP)-conjugated $\beta$-actin (1:5,000 dilution) with gentle agitation at $37^{\circ} \mathrm{C}$ overnight followed by further incubation with HRP-conjugated secondary antibodies (1:5,000 dilution; Wuhan Boster Biological Technology, Ltd., Wuhan, China) for $1.5 \mathrm{~h}$ at room temperature. The immunoreactive signals were visualized using an enhanced chemiluminescence (ECL) detection system (Applygen Technologies, Inc., Beijing, China). For quantifying the protein expression, the X-ray films were scanned and analyzed with ImageJ 1.410 software.

Data analysis and statistics. All data were presented as the mean \pm SD. Differences between groups were analyzed by one-way analyses of variance (ANOVA) with SPSS 13.0 (SPSS, Inc.). $\mathrm{P}<0.05$ was considered to indicate statistical significance.

\section{Results}

Preconditioning with $\mathrm{H}_{2} \mathrm{O}_{2}$ upregulates expression of $\mathrm{HO}-1$. To identify whether $\mathrm{H}_{2} \mathrm{O}_{2}$ preconditioning induces the expression of $\mathrm{HO}-1, \mathrm{PC} 12$ cells were treated with $100 \mu \mathrm{M} \mathrm{H}_{2} \mathrm{O}_{2}$ for $90 \mathrm{~min}$, and the samples were harvested at the indicated times (3, 6 and $9 \mathrm{~h}$ ) after $\mathrm{H}_{2} \mathrm{O}_{2}$ preconditioning. The results of western blotting analysis (Fig. 1) showed that treatment with $\mathrm{H}_{2} \mathrm{O}_{2}$ induced a significant increase in HO-1 expression compared with the control group. Within 3-9 h after $\mathrm{H}_{2} \mathrm{O}_{2}$ preconditioning, there was a consistent increase in the expression of $\mathrm{HO}-1$, which peaked at $6 \mathrm{~h}$.

HO- 1 contributes to the cytoprotection of $\mathrm{H}_{2} \mathrm{O}_{2}$ preconditioning against oxidative stress-induced injury. To confirm whether HO-1 is involved in the adaptive cytoprotection of $\mathrm{H}_{2} \mathrm{O}_{2}$ preconditioning, we first examined the role of HO-1 in the protective effect of $\mathrm{H}_{2} \mathrm{O}_{2}$ preconditioning against cytotoxicity induced by $\mathrm{H}_{2} \mathrm{O}_{2}$. As shown in Fig. 2A, exposure of PC12 cells to $\mathrm{H}_{2} \mathrm{O}_{2}$ at $300 \mu \mathrm{M}$ for $12 \mathrm{~h}$ obviously attenuated cell viability $(\mathrm{P}<0.01)$. Preconditioning with $100 \mu \mathrm{M} \mathrm{H}_{2} \mathrm{O}_{2}$
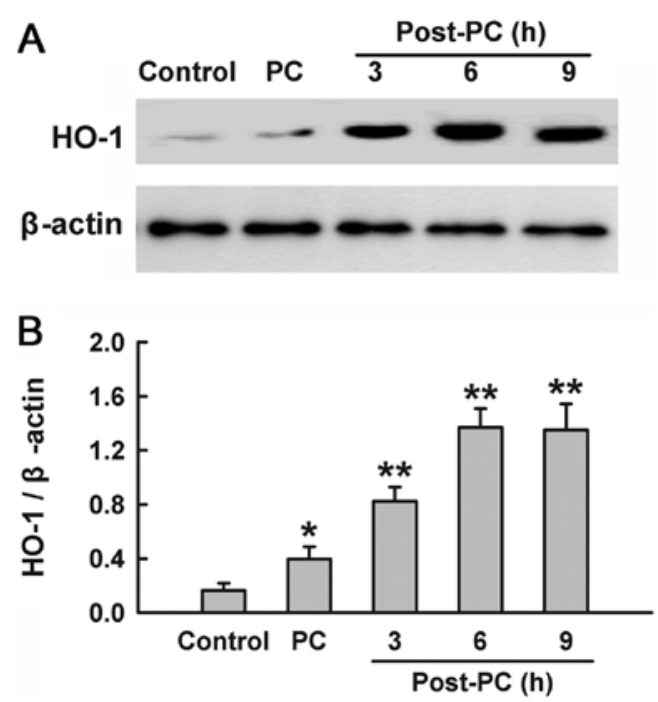

Figure 1. $\mathrm{H}_{2} \mathrm{O}_{2}$ preconditioning induced the expression of HO-1. (A) PC12 cells were pretreated with $\mathrm{H}_{2} \mathrm{O}_{2}$ at $100 \mu \mathrm{M}$ for 90 min followed by culturing for the indicated time (i.e. 3, 6 and $9 \mathrm{~h}$ ). Western blotting assay was used to detect HO-1 expression. (B) Densitometric analysis of HO-1 expression in (A). Data were shown as mean $\pm \mathrm{SD}, \mathrm{n}=3 .{ }^{*} \mathrm{P}<0.05 ;{ }^{* *} \mathrm{P}<0.01$ vs. control group.

inhibited the $300 \mu \mathrm{M} \mathrm{H}_{2} \mathrm{O}_{2}$-induced decrease in cell viability. Preconditioning with $100 \mu \mathrm{M} \mathrm{H}_{2} \mathrm{O}_{2}$ for 90 min alone did not markedly alter the viability. Importantly, this anti-cytotoxic effect of $\mathrm{H}_{2} \mathrm{O}_{2}$ preconditioning was blocked by treatment with $15 \mu \mathrm{M} \mathrm{ZnPP}$ for 20 min prior to preconditioning with $\mathrm{H}_{2} \mathrm{O}_{2}$, indicating that HO-1 mediates the adaptive cytoprotection of $\mathrm{H}_{2} \mathrm{O}_{2}$ preconditioning against cytotoxicity induced by oxidative stress.

Secondarily, we detected the role of HO-1 in the cytoprotection of $\mathrm{H}_{2} \mathrm{O}_{2}$ preconditioning from $\mathrm{H}_{2} \mathrm{O}_{2}$-elicited apoptosis. Exposure to $300 \mu \mathrm{M} \mathrm{H}_{2} \mathrm{O}_{2}$ obviously elevated the caspases-3/ -7 activation in PC12 cells (Fig. 2B). The increased activities of caspases -3 and -7 induced by $\mathrm{H}_{2} \mathrm{O}_{2}$ were inhibited by $100 \mu \mathrm{M} \mathrm{H}_{2} \mathrm{O}_{2}$ preconditioning. However, ZnPP at $15 \mu \mathrm{M}$ blocked the protective effect of $\mathrm{H}_{2} \mathrm{O}_{2}$ preconditioning against the $\mathrm{H}_{2} \mathrm{O}_{2}$-induced caspases-3/-7 activation. In addition, the results of flow cytometric analysis (Fig. 2C and D) showed that exposure of cells to $300 \mu \mathrm{M} \mathrm{H}_{2} \mathrm{O}_{2}$ for $12 \mathrm{~h}$ obviously enhanced the percentage of apoptotic cells $(\mathrm{P}<0.01)$, which was reduced by preconditioning with $\mathrm{H}_{2} \mathrm{O}_{2}$. Preconditioning with $100 \mu \mathrm{M}$ $\mathrm{H}_{2} \mathrm{O}_{2}$ alone had no significant effect on apoptosis. Notably, treatment with $15 \mu \mathrm{M} \mathrm{ZnPP}$ for $20 \mathrm{~min}$ before $\mathrm{H}_{2} \mathrm{O}_{2}$ preconditioning obviously abrogated the anti-apoptotic effect of $\mathrm{H}_{2} \mathrm{O}_{2}$ preconditioning. These results suggest that $\mathrm{HO}-1$ is implicated in the anti-apoptotic effect of preconditioning with $\mathrm{H}_{2} \mathrm{O}_{2}$.

$\mathrm{Next}$, we also found involvement of $\mathrm{HO}-1$ in $\mathrm{H}_{2} \mathrm{O}_{2}$ preconditioning-induced antioxidative stress and mitochondrial protection. As shown in Fig. 2E-H, preconditioning with $100 \mu \mathrm{M} \mathrm{H}_{2} \mathrm{O}_{2}$ considerably attenuated ROS generation (Fig. 2E and $\mathrm{G}$ ) and a loss of $\Delta \Psi \mathrm{m}$ (Fig. 2F and $\mathrm{H}$ ) induced by $300 \mu \mathrm{M} \mathrm{H}_{2} \mathrm{O}_{2}$. However, these protective effects of $\mathrm{H}_{2} \mathrm{O}_{2}$ preconditioning were reversed by treatment with $15 \mu \mathrm{M} \mathrm{ZnPP}$ prior to $\mathrm{H}_{2} \mathrm{O}_{2}$ preconditioning. Alone, $\mathrm{ZnPP}$ did not affect ROS generation or $\Delta \Psi \mathrm{m}$.

Preconditioning with $\mathrm{H}_{2} \mathrm{O}_{2}$ enhances phosphorylation of Akt. Since Akt activation induces HO-1 expression, we explored 

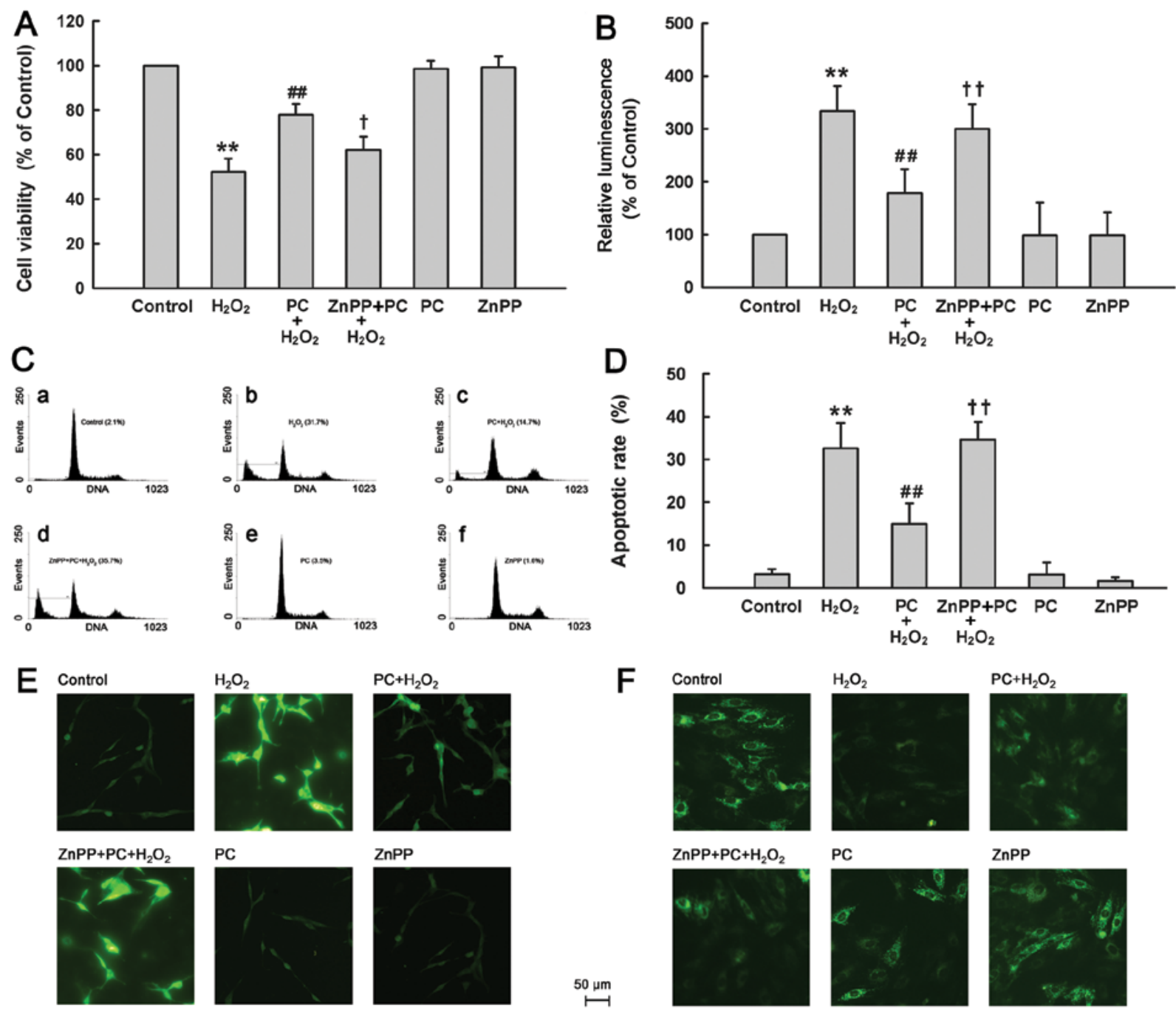

$\mathrm{PC}+\mathrm{H}_{2} \mathrm{O}_{2}$
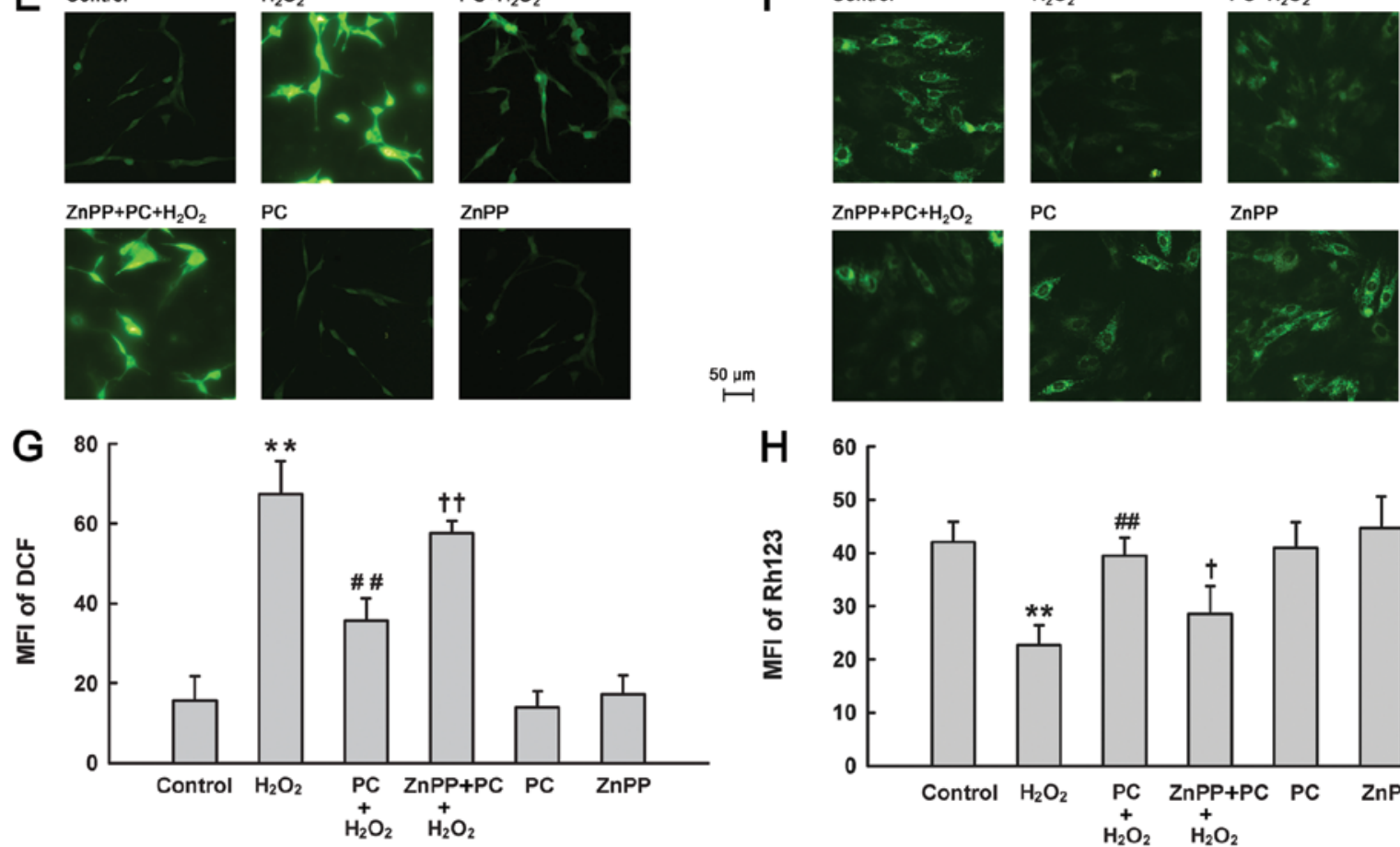

ZnPP

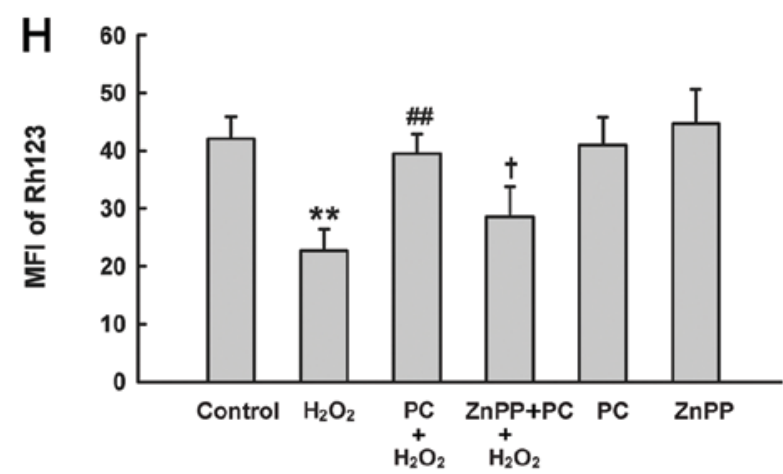

Figure 2. Effects of different treatments on cell injury of PC12 cells. After the indicated treatments, (A) cell viability, (B) activities of caspases-3/-7, (C and D) apoptosis, (E and G) ROS generation and $(\mathrm{F}$ and $\mathrm{H}) \Delta \Psi \mathrm{m}$ were evaluated. Control group, untreated $\mathrm{PC} 12$ cells. $\mathrm{H}_{2} \mathrm{O}_{2}$ group, cells were treated with $300 \mu \mathrm{M}$ $\mathrm{H}_{2} \mathrm{O}_{2}$ for $12 \mathrm{~h}$. $\mathrm{PC}+\mathrm{H}_{2} \mathrm{O}_{2}$ group, cells were preconditioned with $100 \mu \mathrm{M} \mathrm{H}_{2} \mathrm{O}_{2}$ for 90 min before exposure to $300 \mu \mathrm{M} \mathrm{H}_{2} \mathrm{O}_{2}$ for $12 \mathrm{~h}$. $\mathrm{ZnPP}+\mathrm{PC}+\mathrm{H}_{2} \mathrm{O}_{2}$ group, cells were treated with $\mathrm{ZnPP}(15 \mu \mathrm{M})$ for 20 min before $\mathrm{H}_{2} \mathrm{O}_{2}$ preconditioning, followed by exposure to $300 \mu \mathrm{M} \mathrm{H}_{2} \mathrm{O}_{2}$ for $12 \mathrm{~h}$. PC group, PC12 cells were treated with $100 \mu \mathrm{M} \mathrm{H}_{2} \mathrm{O}_{2}$ for $90 \mathrm{~min}$ followed by a further $12 \mathrm{~h}$ culture. ZnPP group, PC12 cells were treated with $15 \mu \mathrm{M} \mathrm{ZnPP}$ for 20 min followed by a further $12 \mathrm{~h}$ culture. Data were presented as mean $\pm \mathrm{SD}, \mathrm{n}=3 .{ }^{* *} \mathrm{P}<0.01$ vs. control group; ${ }^{*} \mathrm{P}<0.05$ vs. $\mathrm{H}_{2} \mathrm{O}_{2}$ group; ${ }^{+} \mathrm{P}<0.05,{ }^{++} \mathrm{P}<0.01$ vs. $\mathrm{PC}+\mathrm{H}_{2} \mathrm{O}_{2}$ group.

the effect of $\mathrm{H}_{2} \mathrm{O}_{2}$ preconditioning on activation of Akt. Preconditioning with $100 \mu \mathrm{M} \mathrm{H}_{2} \mathrm{O}_{2}$ upregulated the expression of p-Akt at specific times $(15,30,60,90,120$ and $180 \mathrm{~min}$ after $\mathrm{H}_{2} \mathrm{O}_{2}$ preconditioning), compared with the control group (Fig. 3). Within 15-90 min after $\mathrm{H}_{2} \mathrm{O}_{2}$ preconditioning, the expression of p-Akt increased in a time-dependent manner, peaking at $90 \mathrm{~min}$, and then gradually decreased at 120 and $180 \mathrm{~min}$. However, $\mathrm{H}_{2} \mathrm{O}_{2}$ preconditioning had no effect on t-Akt expression.
The PI3K/Akt pathway modulates the induction of $\mathrm{HO}-\mathrm{I}$ induced by $\mathrm{H}_{2} \mathrm{O}_{2}$ preconditioning. Since both HO-1 and Akt were activated by $\mathrm{H}_{2} \mathrm{O}_{2}$ preconditioning, we explored the influence of PI3K/Akt pathway on the induction of HO-1 by preconditioning with $\mathrm{H}_{2} \mathrm{O}_{2}$. The expression of HO-1 was significantly upregulated by $\mathrm{H}_{2} \mathrm{O}_{2}$ preconditioning (Fig. 4). The $\mathrm{H}_{2} \mathrm{O}_{2}$ preconditioning-induced overexpression of HO-1 was blocked by treatment with Ly294002 $(25 \mu \mathrm{M})$, a selective 

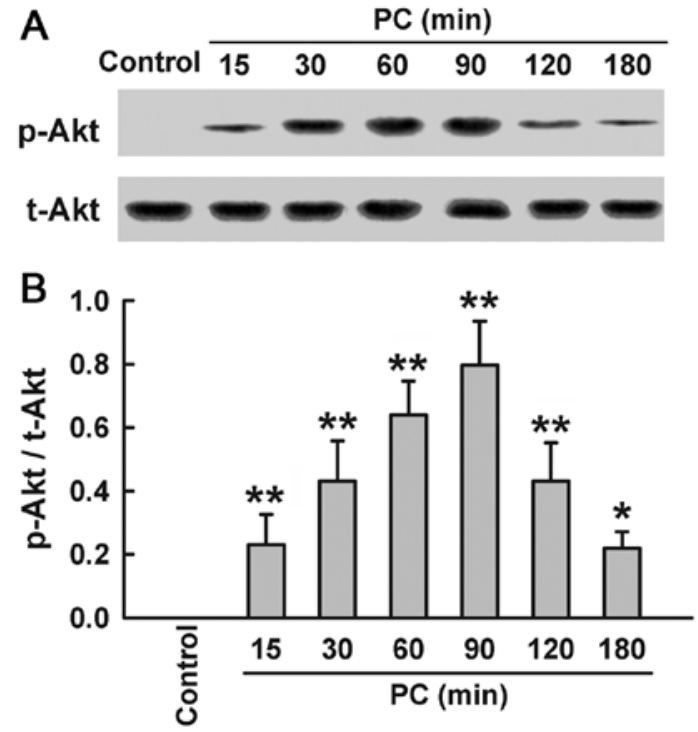

Figure 3. Effect of $\mathrm{H}_{2} \mathrm{O}_{2}$ preconditioning on Akt activation in $\mathrm{PC} 12$ cells. PC12 cells were preconditioned with $100 \mu \mathrm{M} \mathrm{H}_{2} \mathrm{O}_{2}$ for 90 min, the samples were harvested at the indicated time points after $\mathrm{H}_{2} \mathrm{O}_{2}$ preconditioning. (A) Expressions of t-Akt and p-Akt were analyzed by western blotting assay. (B) Densitometric analysis result from (A). Data were presented as mean $\pm \mathrm{SD}, \mathrm{n}=3 .{ }^{*} \mathrm{P}<0.05,{ }^{* *} \mathrm{P}<0.01$ vs. control group.
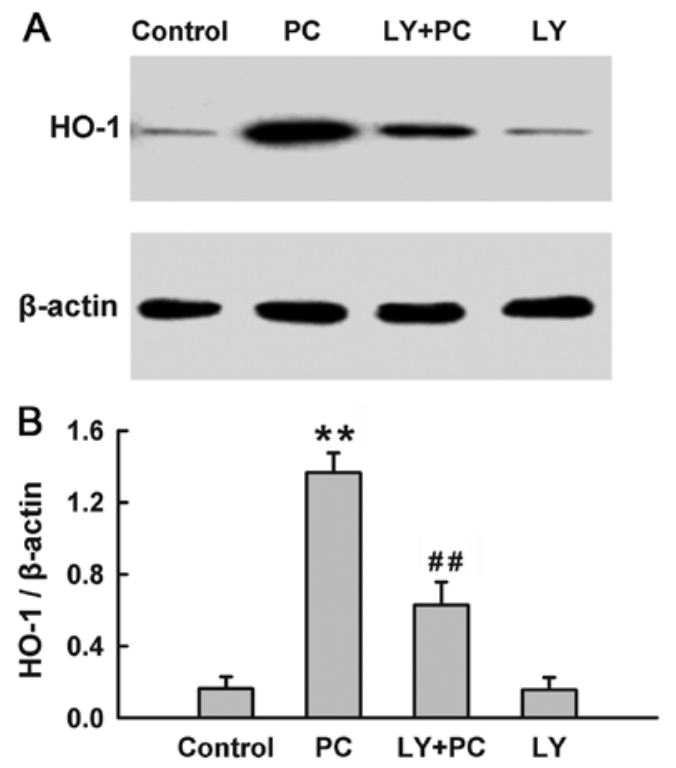

Figure 4. Role of PI3K/Akt pathway in HO-1 induction by $\mathrm{H}_{2} \mathrm{O}_{2}$ preconditioning. (A) After the indicated treatments, western blotting assay was applied to detect HO-1 expression. Control group, normal PC12 cells. PC group, PC12 cells were pretreated with $100 \mu \mathrm{M} \mathrm{H}_{2} \mathrm{O}_{2}$ for $90 \mathrm{~min}$. LY+PC group, PC12 cells were treated with $25 \mu \mathrm{M}$ Ly294002 (a selective inhibitor of PI3K/Akt pathway, LY) for 20 min before $\mathrm{H}_{2} \mathrm{O}_{2}$ preconditioning. LY group, PC12 cells were treated with Ly294002 $(25 \mu \mathrm{M})$ for $20 \mathrm{~min}$. The samples were harvested at $6 \mathrm{~h}$ after $\mathrm{H}_{2} \mathrm{O}_{2}$ preconditioning. (B) Densitometric analysis for the changes in expression of HO-1 in (A). Data were shown as mean $\pm \mathrm{SD}, \mathrm{n}=3$. ${ }^{* *} \mathrm{P}<0.01$ vs. control group; ${ }^{\# \#} \mathrm{P}<0.01$ vs. $\mathrm{PC}$ group.

inhibitor of PI3K/Akt, which was administered for $20 \mathrm{~min}$ before $\mathrm{H}_{2} \mathrm{O}_{2}$ preconditioning. Alone, Ly294002 did not alter the basal expression of HO-1. These findings suggest that the $\mathrm{H}_{2} \mathrm{O}_{2}$ preconditioning-induced overexpression of $\mathrm{HO}-1$ is dependent on the activation of the PI3K/Akt pathway.

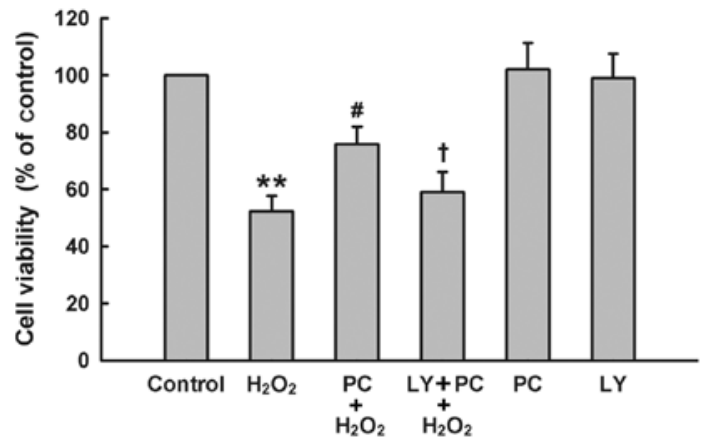

Figure 5. The PI3K/Akt pathway mediates the anti-cytotoxic effect of $\mathrm{H}_{2} \mathrm{O}_{2}$ preconditioning. After different treatments, the MTT reduction assay was used to assess cell viability. Control group, normal cells. $\mathrm{H}_{2} \mathrm{O}_{2}$ group, cells were treated with $300 \mu \mathrm{M} \mathrm{H}_{2} \mathrm{O}_{2}$ for $12 \mathrm{~h}$. $\mathrm{PC}+\mathrm{H}_{2} \mathrm{O}_{2}$ group, cells were preconditioned with $100 \mu \mathrm{M} \mathrm{H}_{2} \mathrm{O}_{2}$ for 90 min before exposure to $300 \mu \mathrm{M} \mathrm{H}_{2} \mathrm{O}_{2}$ for $12 \mathrm{~h}$. $\mathrm{LY}+\mathrm{PC}+\mathrm{H}_{2} \mathrm{O}_{2}$ group, cells were treated with Ly294002 $(25 \mu \mathrm{M})$ for 20 min before $\mathrm{H}_{2} \mathrm{O}_{2}$ preconditioning, followed by exposure to $300 \mu \mathrm{M} \mathrm{H}_{2} \mathrm{O}_{2}$ for $12 \mathrm{~h}$. PC group, PC12 cells were preconditioned with $100 \mu \mathrm{M} \mathrm{H}_{2} \mathrm{O}_{2}$ for $90 \mathrm{~min}$ followed by a further $12 \mathrm{~h}$ culture. LY group, cells were treated with $25 \mu \mathrm{M}$ Ly294002 for $20 \mathrm{~min}$ alone followed by a further $12 \mathrm{~h}$ culture. Data were shown as mean $\pm \mathrm{SD}, \mathrm{n}=3$. ${ }^{* *} \mathrm{P}<0.01$ vs. control group; ${ }^{\#} \mathrm{P}<0.05$ vs. $\mathrm{H}_{2} \mathrm{O}_{2}$ group; ${ }^{\dagger} \mathrm{P}<0.05$ vs. $\mathrm{PC}+\mathrm{H}_{2} \mathrm{O}_{2}$ group.

The PI3K/Akt pathway mediates the cytoprotective effect of $\mathrm{H}_{2} \mathrm{O}_{2}$ preconditioning against oxidative stress-induced cytotoxicity. To further demonstrate the role of PI3K/Akt pathway in the cytoprotection of $\mathrm{H}_{2} \mathrm{O}_{2}$ preconditioning against oxidative stress, PC12 cells were treated with Ly294002 $(25 \mu \mathrm{M})$ for 20 min prior to $\mathrm{H}_{2} \mathrm{O}_{2}$ preconditioning. The results of Fig. 5 showed that $\mathrm{H}_{2} \mathrm{O}_{2}$ preconditioning protected PC12 cells against $\mathrm{H}_{2} \mathrm{O}_{2}$-induced cytotoxicity, evidenced by an increase in cell viability. Treatment of cells with Ly294002 at $25 \mu \mathrm{M}$ significantly blocked the anti-cytotoxic effect of $\mathrm{H}_{2} \mathrm{O}_{2}$ preconditioning. Ly294002 alone had no effect on cell viability in PC12 cells. These findings indicate that the PI3K/Akt pathway participates in the protection of $\mathrm{H}_{2} \mathrm{O}_{2}$ preconditioning against $\mathrm{H}_{2} \mathrm{O}_{2}$-induced cytotoxicity in PC12 cells.

\section{Discussion}

Based on our previous studies (10-13), this study further demonstrates that PC12 cells have intrinsic mechanisms that respond to a brief exposure to oxidative stress by enhancing cellular resistance to the induction of oxidative injuries by subsequent sustained oxidative exposure. Here, we provide new evidence for a key mechanism that the PI3K/Akt-HO-1 pathway plays a critical role in the adaptive cytoprotective effect of oxidative $\left(\mathrm{H}_{2} \mathrm{O}_{2}\right)$ preconditioning against oxidative stress injuries in PC12 cells. This is strongly supported by the findings that i) $\mathrm{H}_{2} \mathrm{O}_{2}$ preconditioning enhanced the expression of HO-1; ii) inhibition of HO-1 by ZnPP blocked the cytoprotection of $\mathrm{H}_{2} \mathrm{O}_{2}$ preconditioning against oxidative injuries, evidenced by the decreases in cell viability and $\Delta \Psi \mathrm{m}$, and increases in apoptotic cells, ROS generation as well as caspases-3 and -7 activities; iii) the expression of p-Akt was upregulated by $\mathrm{H}_{2} \mathrm{O}_{2}$ preconditioning; iv) Ly294002, a selective inhibitor of $\mathrm{PI} 3 \mathrm{~K}$, attenuated $\mathrm{H}_{2} \mathrm{O}_{2}$ preconditioning-induced overexpression of $\mathrm{HO}-1$, indicating the regulatory effect of the PI3K/Akt pathway on the expression of HO-1; v) Ly294002 blocked the protective effect of $\mathrm{H}_{2} \mathrm{O}_{2}$ preconditioning against 
oxidative stress-elicited cytotoxicity, suggesting the involvement of the PI3K/Akt pathway in the adaptive cytoprotection of preconditioning with $\mathrm{H}_{2} \mathrm{O}_{2}$.

$\mathrm{HO}$ is the rate-limiting enzyme of microsomal heme degradation. Three isoforms of HO, HO-1, HO-2 and HO-3, have been characterized. It has been shown that both $\mathrm{HO}-2$ and HO-3 are constitutively expressed whereas HO- 1 is an inducible isoform with low basal expression (14). HO-2 functions as a physiologic regulator of cellular function and $\mathrm{HO}-3$ appears to have only low enzyme activity, whereas HO-1 plays a critical role in modulating tissue responses to injury in pathophysiologic states $(21,27,31)$. HO-1 is induced by a variety of cell- and species-dependent stress factors including oxidative stress $(27,31,32)$. Increasing evidence reveals that HO-1 has antioxidant $(14,21,27,33)$, anti-apoptotic $(19,32)$, and cytoprotective effects, including neuroprotection $(14,20,21,33)$. Therefore, the role of HO-1 in adaptive cytoprotection has been investigated.

In human proximal tubular (HK-2) cells, HO-1 is involved in the protective effect of oxidant preconditioning against lethal oxidant injury (8). In human lymphocytes, HO-1 mediates the adaptive cytoprotection of HBO preconditioning (22). In addition, cardiac ischemic preconditioning fails to occur in HO-1 knockout mice, suggesting an important role of HO-1 in mediating tissue protection by ischemic preconditioning. HO-1 also contributes to the cardioprotection of $\mathrm{H}_{2} \mathrm{O}_{2}$ preconditioning from oxidative stress in rat neonatal cardiomyocytes (9). However, whether HO-1 is implicated in the neuroprotective effect of $\mathrm{H}_{2} \mathrm{O}_{2}$ preconditioning against oxidative stress injury remains unknown. In the present study, we found that preconditioning with $\mathrm{H}_{2} \mathrm{O}_{2}$ upregulated the expression of $\mathrm{HO}-1$ in PC12 cells. Inhibition of HO- 1 by ZnPP significantly blocked the adaptive cytoprotection of $\mathrm{H}_{2} \mathrm{O}_{2}$ preconditioning against oxidative stress injuries, characterized by increases in cytotoxicity, apoptotic cells, activities of caspases-3/-7, ROS generation and a loss of MMP, suggesting that HO-1 contributes to the anti-cytotoxic, anti-apoptotic and antioxidative effects as well as mitochondrial improvement induced by $\mathrm{H}_{2} \mathrm{O}_{2}$ preconditioning. Our findings are comparable with those previous studies $(8,9,22)$. This study and others $(8,22)$ reveal that HO-1 may be an important intrinsic mediator involved in preconditioning-induced adaptive cytoprotection, in particular, oxidative preconditioning.

Accumulating evidence indicates that $\mathrm{HO}-1$ is highly inducible by agents causing oxidative stress, such as $\mathrm{H}_{2} \mathrm{O}_{2}(14,22,32)$. HO-1 induction is often connected with increased resistance to oxidant-mediated cell injury. Multiple mechanisms are involved in the protection of HO-1 from pathophysiological conditions. One of the key mechanisms may be associated with its antioxidant effect. For example, bilirubin, one of the main byproducts of the catabolism of heme by HO-1, acts as a radical scavenger (32); nanomolar amounts of bilirubin can reduce micromolar amounts of $\mathrm{H}_{2} \mathrm{O}_{2}$ (34). The increased formation of this antioxidant could therefore explain the observed roles of HO-1 in the adaptive protection of $\mathrm{H}_{2} \mathrm{O}_{2}$ preconditioning. Besides an increased bililrubin production, both $\mathrm{CO}$ and ferritin (another product of HO-1 enzyme activity) have also been shown to have an antioxidant effect $(32,35,36)$, which might also contribute to the cytoprotection of $\mathrm{H}_{2} \mathrm{O}_{2}$ preconditioning. Moreover, other antioxidant enzymes may be regulated by byproducts of $\mathrm{HO}-1$ activity, thus contributing to ROS detoxification. For example, HO-1 activates the expression of mitochondrial superoxide dismutase in neonatal rat astroglia challenged with dopamine (37). Furthermore, it has been demonstrated that upregulation of HO-1 improves mitochondrial function and prevents ATP depletion after oxidative stress (38). Noteworthily, some reports have suggested a duality of effects of HO-1 overexpression in oxidative stress $(39,40)$. The release of ferric iron from the porphyrin ring of heme may result in detrimental effects, because this form of iron is known to catalyze oxidative stress (41).

Akt is a central node in cell signaling downstream of growth factors, cytokines, and other cellular stimuli. Akt can promote cell survival and protect against apoptosis initiated by the mitochondrial pathway through phosphorylation and inhibition of the mitochondrial pro-apototic proteins Bad, Bax and caspase-9 (42). Since HO-1 is induced by $\mathrm{H}_{2} \mathrm{O}_{2}$ preconditioning, and has been identified as a new substrate of Akt (43), we explored the effect of preconditioning with $\mathrm{H}_{2} \mathrm{O}_{2}$ on the activation of Akt. The results of this study showed that preconditioning markedly enhanced the expression of $\mathrm{p}-\mathrm{Akt}$, indicating that Akt is activated by preconditioning with $\mathrm{H}_{2} \mathrm{O}_{2}$. These results are consistent with previous evidence that Akt is rapidly activated in response to strong oxidants, such as $\mathrm{H}_{2} \mathrm{O}_{2}$ $(44,45)$ and that oxidative preconditioning increases Akt activation in L-cells (7). In agreement with findings of previous studies $(9,43)$, we found that Ly294002, a selective inhibitor of PI3K, blocked the induction of $\mathrm{HO}-1$ by $\mathrm{H}_{2} \mathrm{O}_{2}$ preconditioning, suggesting that the PI3K/Akt pathway mediates the expression of HO-1. Similarly, recent studies have shown the transcriptional regulation of $\mathrm{HO}-1$ by the PI3K/Akt pathway in response to nerve growth factor and to the antioxidant polyphenol, carnosol $(27,30)$. Importantly, our data showed that treatment with Ly294002 also blocked the protective effects of $\mathrm{H}_{2} \mathrm{O}_{2}$ preconditioning against cytotoxicity induced by $\mathrm{H}_{2} \mathrm{O}_{2}$, which is comparable with the findings reported by Han et al (7) and Angeloni et al (9). These results suggest that the PI3K/Akt pathway is involved in the adaptive effect of $\mathrm{H}_{2} \mathrm{O}_{2}$ preconditioning.

In conclusion, we have provided new evidence to elucidate an important mechanism responsible for the adaptive cytoprotective effect of $\mathrm{H}_{2} \mathrm{O}_{2}$ preconditioning against oxidative stress-induced injuries, including cytotoxicity, apoptosis and mitochondrial dysfunction in PC12 cells. We have observed that activation of PI3K/Akt-HO-1 pathway is involved in the protective effects of oxidative preconditioning. A better understanding of the role of PI3K/Akt-HO-1 pathway in the adaptive cytoprotection against oxidative stress may provide new therapeutic approaches for oxidative stress-related diseases. The findings of this study also support the notion that the lower levels of ROS generated by physiological metabolism may continually precondition cells and defend them against oxidative stress-induced insults under both physiological and pathophysiological conditions.

\section{Acknowledgements}

This study was supported by the Science and Technology Planning Project of the Guangdong province in China (no. 2010B080701035). 


\section{References}

1. Murry CE, Jennings RB and Reimer KA: Preconditioning with ischemia: a delay of lethal cell injury in ischemic myocardium. Circulation 74: 1124-1136, 1986.

2. Khaliulin I, Halestrap AP and Suleiman MS: Temperature preconditioning is optimal at $26^{\circ} \mathrm{C}$ and confers additional protection to hypothermic cardioplegic ischemic arrest. Exp Biol Med (Maywood) 236: 736-745, 2011.

3. Lin HJ, Wang CT, Niu KC, et al: Hypobaric hypoxia preconditioning attenuates acute lung injury during high-altitude exposure in rats via up-regulating heat-shock protein 70. Clin Sci 121: 223-231, 2011.

4. Shukla D, Saxena S, Jayamurthy P, et al: Hypoxic preconditioning with cobalt attenuates hypobaric hypoxia-induced oxidative damage in rat lungs. High Alt Med Biol 10: 57-69, 2009.

5. de Klaver MJ, Manning L, Palmer LA, et al: Isoflurane pretreatment inhibits cytokine-induced cell death in cultured rat smooth muscle cells and human endothelial cells. Anesthesiology 97: 24-32, 2002.

6. Zaugg M, Lucchinetti E, Garcia C, et al: Anaesthetics and cardiac preconditioning. Part II. Clinical implications. Br J Anaesth 91: 566-576, 2003.

7. Han $\mathrm{H}$, Wang $\mathrm{H}$, Long $\mathrm{H}$, et al: Oxidative preconditioning and apoptosis in L-cells. Roles of protein kinase B and mitogenactivated protein kinases. J Biol Chem 276: 26357-26364, 2001.

8. Lee HT, Xu H, Ota-Setlik A, et al: Oxidant preconditioning protects human proximal tubular cells against lethal oxidant injury via p38 MAPK and heme oxygenase-1. Am J Nephrol 23 324-333, 2003

9. Angeloni C, Motori E, Fabbri D, et al: $\mathrm{H}_{2} \mathrm{O}_{2}$ preconditioning modulates phase II enzymes through p38 MAPK and PI3K/Akt activation. Am J Physiol Heart Circ Physiol 300: H2196-H2205, 2011.

10. Tang XQ, Feng JQ, Chen J, et al: Protection of oxidative preconditioning against apoptosis induced by $\mathrm{H}_{2} \mathrm{O}_{2}$ in $\mathrm{PC} 12$ cells: mechanisms via MMP, ROS, and Bcl-2. Brain Res 1057: 57-64, 2005.

11. Tang XQ, Yu HM, Zhi JL, et al: Inducible nitric oxide synthase and cyclooxgenase-2 mediate protection of hydrogen peroxide preconditioning against apoptosis induced by oxidative stress in PC12 cells. Life Sci 79: 870-876, 2006.

12. Yu HM, Zhi JL, Cui Y, et al: Role of the JAK-STAT pathway in protection of hydrogen peroxide preconditioning agains apoptosis induced by oxidative stress in PC12 cells. Apoptosis 11: 931-941, 2006

13. Zhang M, Guo RX, Mo LQ, et al: Nuclear factor-kappaB mediates cytoprotection of hydrogen peroxide preconditioning against apoptosis induced by oxidative stress in PC12 cells. Clin Exp Pharmacol Physiol 36: 304-311, 2009.

14. Chen K, Gunter K and Maines MD: Neurons overexpressing heme oxygenase-1 resist oxidative stress-mediated cell death. J Neurochem 75: 304-313, 2000.

15. Maines MD: Bile pigments: newcomers to the cell signaling arena Toxicol Sci 71: 9-10, 2003

16. Mazza F, Goodman A, Lombardo G, et al: Heme oxygenase-1 gene expression attenuates angiotensin II-mediated DNA damage in endothelial cells. Exp Biol Med (Maywood) 228: 576-583, 2003

17. Chen J, Tu Y, Moon C, et al: Heme oxygenase-1 and heme oxygenase-2 have distinct roles in the proliferation and survival of olfactory receptor neurons mediated by cGMP and bilirubin, respectively. J Neurochem 85: 1247-1261, 2003.

18. Poss KD and Tonegawa S: Reduced stress defense in heme oxygenase 1-deficient cells. Proc Natl Acad Sci USA 94: 10925-10930, 1997.

19. Ferris CD, Jaffrey SR, Sawa A, et al: Haem oxygenase-1 prevents cell death by regulating cellular iron. Nat Cell Biol 1: 152-157, 1999.

20. Kretz A, Schmeer C, Tausch S, et al: Simvastatin promotes heat shock protein 27 expression and Akt activation in the rat retina and protects axotomized retinal ganglion cells in vivo. Neurobiol Dis 21: 421-430, 2006

21. Canas N, Valero T, Villarroya M, et al: Chondroitin sulfate protects SH-SY5Y cells from oxidative stress by inducing heme oxygenase-1 via phosphatidylinositol 3-kinase/Akt. J Pharmacol Exp Ther 323: 946-953, 2007.

22. Speit G, Dennog C, Eichhorn U, et al: Induction of heme oxygenase-1 and adaptive protection against the induction of DNA damage after hyperbaric oxygen treatment. Carcinogenesis 21: $1795-1799,2000$
23. Rothfuss A, Radermacher P and Speit G: Involvement of heme oxygenase-1 (HO-1) in the adaptive protection of human lymphocytes after hyperbaric oxygen (HBO) treatment. Carcinogenesis 22: 1979-1985, 2001

24. Ha T, Hu Y, Liu L, et al: TLR2 ligands induce cardioprotection against ischaemia/reperfusion injury through a PI3K/ Akt-dependent mechanism. Cardiovasc Res 87: 694-703, 2010.

25. Ha T, Hua F, Liu X, et al: Lipopolysaccharide-induced myocardial protection against ischaemia/reperfusion injury is mediated through a PI3K/Akt-dependent mechanism. Cardiovasc Res 78 546-553, 2008.

26. Arruda MA, Rossi AG, de Freitas MS, et al: Heme inhibits human neutrophil apoptosis: involvement of phosphoinositide 3-kinase, MAPK, and NF-kappaB. J Immunol 173: 2023-2030, 2004.

27. Salinas M, Diaz R, Abraham NG, et al: Nerve growth factor protects against 6-hydroxydopamine-induced oxidative stress by increasing expression of heme oxygenase-1 in a phosphatidylinositol 3-kinase-dependent manner. J Biol Chem 278: 13898-13904, 2003.

28. Chung SW, Chen YH and Perrella MA: Role of Ets-2 in the regulation of heme oxygenase-1 by endotoxin. J Biol Chem 280: 4578-4584, 2005

29. Ivanov VN and Hei TK: Combined treatment with EGFR inhibitors and arsenite upregulated apoptosis in human EGFR-positive melanomas: a role of suppression of the PI3K-Akt pathway. Oncogene 24: 616-626, 2005.

30. Martin D, Rojo AI, Salinas M, et al: Regulation of heme oxygenase-1 expression through the phosphatidylinositol3-kinase/ Akt pathway and the Nrf2 transcription factor in response to the antioxidant phytochemical carnosol. J Biol Chem 279: 8919-8929, 2004.

31. Kikuchi G, Yoshida T and Noguchi M: Heme oxygenase and heme degradation. Biochem Biophys Res Commun 338: 558-567, 2005.

32. Parfenova $\mathrm{H}$, Basuroy $\mathrm{S}$, Bhattacharya $\mathrm{S}$, et al: Glutamate induces oxidative stress and apoptosis in cerebral vascular endothelial cells: contributions of HO-1 and HO-2 to cytoprotection. Am J Physiol Cell Physiol 290: C1399-C1410, 2006.

33. Rossler OG, Bauer I, Chung HY, et al: Glutamate-induced cell death of immortalized murine hippocampal neurons: neuroprotective activity of heme oxygenase-1, heat shock protein 70 , and sodium selenite. Neurosci Lett 362: 253-257, 2004.

34. Dore S, Takahashi M, Ferris CD, et al: Bilirubin, formed by activation of heme oxygenase-2, protects neurons against oxidative stress injury. Proc Natl Acad Sci USA 96: 2445-2450, 1999.

35. Vile GF, Basu-Modak S, Waltner C, et al: Heme oxygenase 1 mediates an adaptive response to oxidative stress in human skin fibroblasts. Proc Natl Acad Sci USA 91: 2607-2610, 1994.

36. Soares MP, Usheva A, Brouard S, et al: Modulation of endothelia cell apoptosis by heme oxygenase-1-derived carbon monoxide. Antioxid Redox Signal 4: 321-329, 2002.

37. Frankel D, Mehindate K and Schipper HM: Role of heme oxygenase- 1 in the regulation of manganese superoxide dismutase gene expression in oxidatively-challenged astroglia. J Cell Physiol 185: 80-86, 2000.

38. Bornman L, Steinmann CM, Gericke GS, et al: In vivo heat shock protects rat myocardial mitochondria. Biochem Biophys Res Commun 246: 836-840, 1998.

39. Suttner DM and Dennery PA: Reversal of HO-1 related cytoprotection with increased expression is due to reactive iron. FASEB J 13: $1800-1809,1999$

40. Suttner DM, Sridhar K, Lee CS, et al: Protective effects of transient HO-1 overexpression on susceptibility to oxygen toxicity in lung cells. Am J Physiol 276: L443-L451, 1999.

41. Gutteridge JM, Rowley DA and Halliwell B: Superoxidedependent formation of hydroxyl radicals and lipid peroxidation in the presence of iron salts. Detection of 'catalytic' iron and antioxidant activity in extracellular fluids. Biochem J 206: 605-609, 1982.

42. Manning BD and Cantley LC: Akt/PKB signaling: navigating downstream. Cell 129: 1261-1274, 2007.

43. Salinas M, Wang J, Rosa de Sagarra M, et al: Protein kinase $\mathrm{Akt} / \mathrm{PKB}$ phosphorylates heme oxygenase-1 in vitro and in vivo. FEBS Lett 578: 90-94, 2004

44. Martin D, Salinas M, Fujita N, et al: Ceramide and reactive oxygen species generated by $\mathrm{H}_{2} \mathrm{O}_{2}$ induce caspase-3-independent degradation of Akt/protein kinase B. J Biol Chem 277: 42943-42952, 2002.

45. Wang X, McCullough KD, Franke TF, et al: Epidermal growth factor receptor-dependent Akt activation by oxidative stress enhances cell survival. J Biol Chem 275: 14624-14631, 2000. 